\title{
Nutrition Profile of the Destitute Women and Children in a Selected Rehabilitation Centre in Gazipur
}

\author{
Nazmul Hassan and Taniza Hossain * \\ Institute of Nutrition and Food Science, University of Dhaka, Dhaka-1000
}

\begin{abstract}
The present study attempts to identify the nutrition profile of the destitute women and children living in a rehabilitation center, Shishu Polli Plus (SPP), Gazipur. The vision of SPP is to serve underprivileged orphan children and destitute women and rehabilitate them by providing education and skill training. Information on anthropometric data, dietary intake, prevalence of morbidity and health and nutrition knowledge of SPP beneficiaries were collected by visiting the rehabilitation center. Dietary intake was calculated using dietary weighing of 7 consecutive days. Mean energy intake of SPP inmates was $1759 \mathrm{Kcal}$ ( $86 \%$ of RDA). Mean intake of other nutrients were- protein $43 \mathrm{~g}$, fat $33 \mathrm{~g}$, CHO $325 \mathrm{~g}$, calcium $307 \mathrm{mg}$, iron $17 \mathrm{mg}$, vitamin A $4120 \mathrm{IU}$, thiamine $1.21 \mathrm{mg}$, riboflavin $0.59 \mathrm{mg}$ and vitamin C $61 \mathrm{mg}$. They fulfilled the RDA for protein $(96 \%)$, vitamin A $(240 \%)$, and thiamine $(118 \%)$. They were deficient in calcium ( $61 \%$ of RDA), iron $(77 \%$ of RDA), riboflavin ( $48 \%$ of $\mathrm{RDA})$ and vitamin $\mathrm{C}(130 \%$ of RDA; without considering cooking loss). Anthropometric assessments of the inmates indicated the presence of double burden of malnutrition at SPP. The great majority of the children (specially under-5) were undernourished; while at the same time about $9 \%$ of all adult women were found obese (BMI $>25)$. Overall one in five children in SPP was found to be stunted. The situation however changes dramatically with age. A higher prevalence of stunting was reported with the lower age group of children. According to the weight for age and weight for height classification of nutritional status, about 30 per cent of all children residing at SPP were underweight and one quarter of all SPP children were wasted. SPP environmental hygiene was much appreciated and the personal hygiene of SPP was far better than those of their counterparts in rural areas. The morbidity reporting was very few except for skin diseases. But SPP inmates' knowledge on nutrition and health was very poor. The study findings are encouraging in that the dietary intakes, anthropometry and the knowledge base (nutrition and health) of the SPP beneficiaries are comparable to those of their counterparts in the rural Bangladesh. This implies that without SPP interventions and attention the real life situation for these inmates would have been different. SPP has been trying very hard to bring meaningful changes in the life and living of these destitute.
\end{abstract}

Key Words: Nutrition Profile, Destitute, Women, Children, Rehabilitation Centre.

Bangladesh Journal of Nutrition. Vol 18-19, December 2005-2006. Institute of Nutrition and Food Science, University of Dhaka-1000, Bangladesh.

\footnotetext{
Author for Correspondence
} 


\section{Introduction}

Mother and children belonging to poor socio-economic status, in general, are observed to be malnourished in Bangladesh. The nutritional status of the orphans and destitute are perhaps still worse. Destitution is an extreme state of poverty, in which a person is almost completely lacking in resources or means of support. A person who is destitute is often homeless, unemployed and hungry. Destitution often leads to starvation and death. Besides food, destitute children are deprived of the warmth of parents' affection required for their mental and psychological development. A women is considered destitute if she (i) either is widowed or abandoned or has only a disabled husband and (ii) is functionally landless (owning less than 0.4 acre [ $0.16 \mathrm{ha}$ ] of cultivable land) and asset less ${ }^{1}$. It is estimated that ${ }^{2}$ about $30 \%$ of all rural women over the age of ten in Bangladesh are destitute; if urban dwellers are added to this estimate, such women would number in tens of millions. Yunus ${ }^{3}$ also agrees to this estimate and further claims, "There are millions of [destitute women] .... in_Bangladesh who continue to be deprived of any ray of hope."

In recent years, destitute have started drawing attention of the government as well as of the NGO's, as revealed by the proliferation of Shishu Polli (children's village) orphanages, and pathakali (street children) trust etc. in our country. These organizations attempt to bring the destitute orphans, and in some cases the abandoned female sex workers from the prostitutes back to a better life and provide them with all possible facilities including education and skill training for their well upbringing. They are given better food, housing, medication, education, recreation and facilities for supports compared to their earlier situation. Thus they are to lead their life in an organized and controlled situation, everyone being exposed to more or less similar dietary and environmental situations.

In the present context it is all the more important to assess the nutritional status of the orphans and destitute women in order to study the impact of organized institutional feeding and better hygienic condition on the nutritional status of these orphans/destitute women who were consistently reported to be initially malnourished before they were brought to these facilities. There are limited studies on the health and nutrition profile of these destitute being taken care of by these development agencies, NGOs etc. In order to meet this data gap a comprehensive study incorporating different aspect of food, health and nutrition was undertaken with the inmates of the "Shishu Polli Plus" (SPP).

\section{Methodology Study Site}

The study aimed at assessing the nutritional profile of destitute women and the orphan children residing in "Shishu Polli Plus" (SPP). SPP is located in the village Tengra, upazila: Sreepur, district: Gazipur.

\section{Sample Size}

There were 485 beneficiaries in SPP as of March, 2006. All these beneficiaries comprised the sampling unit for the study. The distribution of beneficiaries by age and 
sex group is furnished in table-1. The study has three components: dietary, anthropometric, and morbidity assessments. The anthropometric assessments was carried out on the entire population in residence at SPP. Except for children aged 7-9, adolescents boys belonging to age group 10-17 and adult women (18 and above), dietary and morbidity assessment also had the full head counts. Then for children, adolescent boys and adult women having large population (7-9, 10-17 and 18 and above years of age) samples were selected statistically using systematic sampling method. A total of 60 children belonging to age group 7-9, 23 adolescent boys from age group 10-17 and 64 adult women from age group 18 and above were thus selected for the diet and morbidity component of the study.

Table1: Distribution of SPP beneficiaries by age and sex, March, 2006

\begin{tabular}{|c|c|c|}
\hline Age group (years) & Number of subject & $\%$ of subject \\
\hline \multirow{3}{*}{ Under-5 } & 34 & 7 \\
\hline & 39 & 8 \\
\hline & 73 & 15 \\
\hline \multirow[t]{3}{*}{$5-9$} & 102 & 21 \\
\hline & 90 & 19 \\
\hline & 192 & 40 \\
\hline \multirow[t]{3}{*}{$10-17$} & 46 & 10 \\
\hline & 40 & 8 \\
\hline & 86 & 18 \\
\hline & 10 & 2 \\
\hline $\begin{array}{l}18 \text { and above Male } \\
\text { Female }\end{array}$ & 124 & 26 \\
\hline Both & 134 & 28 \\
\hline \multirow{4}{*}{$\begin{array}{ll}\text { Total } & \begin{array}{l}\text { Male } \\
\text { Female } \\
\text { Both }\end{array} \\
\text { Total Children }(0-17)\end{array}$} & 192 & 40 \\
\hline & 293 & 60 \\
\hline & 485 & 100 \\
\hline & 361 & 75 \\
\hline $\begin{array}{l}\text { Total Children (0-17) } \\
\text { Women (18 \& above) }\end{array}$ & 124 & 25 \\
\hline
\end{tabular}

\section{Development of Survey Questionnaire \& study techniques}

Information on the dietary intakes, anthropometry and morbidity were collected from these selected samples using a prescribed and pre-tested questionnaire. Dietary intake was collected using 24-hour weighing method and a prescribed format. Anthropometric data on height and weight was collected from the selected samples using two types of scales and a standard format. Except for infants, all heights were obtained using a wooden scale and for infants a specially designed wooden scale was used to record recumbent length. Weights were recorded using a bathroom scale. Information on mortality, morbidity, hygiene and other relevant parameters of socio-economic status were obtained by personal interview using a pre-tested questionnaire. All these questionnaires were developed in the light of the objectives set for the study, and in line with prior experience gained with other national levels large-scale studies accomplished by this Institute. 
Bangladesh J. Nutr. Vol. 18-19, December 2005-2006

\section{Data Collection}

The collection of data from selected location was undertaken during the months of March and April (24 $4^{\text {th }}$ March-2 ${ }^{\text {nd }}$ April, 2006).

\section{Results}

A. Food and Nutrient Intakes of the SPP Beneficiaries: This section presents the findings on the dietary intake of the SPP inmates and provides information about the types of food consumed and sources of nutrients. Foods were classified into ten groups. They were then converted into nutrients using Bangladesh food value tables ${ }^{4}$. The nutrients were shown under ten heads.

Table-2 presents the average food intake of the SPP beneficiaries and compares them with those of the national average. The last national nutrition survey was carried out in $1995 / 96$ on statistically selected sample population through out the country ${ }^{5}$. The intakes, as shown, are as purchased raw weight of food consumed. The average food intake for the SPP inmates amounted to $800 \mathrm{~g}$ per person per day as against the national intakes of $728 \mathrm{~g}$. Unlike national intakes, cereals, roots and vegetables constituted the bulk $(80 \%)$ of the intakes in SPP. Average cereal intake was only $273 \mathrm{~g}$ per person per day in SPP as against the national intakes of about $436 \mathrm{~g}$. Cereals constituted $34 \%$ of the total diet in SPP while it constituted $60 \%$ of the total diet in the national intakes. Average intakes of vegetables (both leafy and non-leafy) were $214 \mathrm{~g}$. This constituted about $27 \%$ of the total diet in SPP. Vegetables intake was $112 \mathrm{~g}$ in the national diet and constituted $15 \%$ of the total food intake. SPP diet appears to be more diversified than the national diet, but nutritionally lower quality food such as bottle gourds, white gourds, unripe papaya dominated vegetable, and potato dominated the roots intakes. This is not nutritionally desirable. Average pulse intake was $58 \mathrm{~g}$ and edible oil intake was $24 \mathrm{~g}$ among SPP beneficiaries. SPP pulse intake was five times and that of oil three times higher than those of the national intakes of these foods. Animal food consisting of fish, meat, egg and milk constituted a very minor component of the diet of SPP inmates. Its consumption was $29 \mathrm{~g}$ as against the national intakes of $61 \mathrm{~g}$. Egg intake was $8 \mathrm{~g}$ among SPP beneficiaries and fish was only $4 \mathrm{~g}$. Animal meat was totally absent in their diet. SPP provides fish only once per week. This is not sufficient to bring diet diversity and promote diet quality. Fruit intake at SPP was $33 \mathrm{~g}$ per person per day and Banana dominated the fruit intake. It is to be noted that the survey coincided with season of relative food scarcity $\left(27^{\text {th }}\right.$ March- $2^{\text {nd }}$ April). Fruits are found in plenty during MayAugust and intake of fruits such as mango, jackfruit, pineapple, guava etc. reach their peak at this time of the year. This might be attributed to low intake of nutrient rich fruits at SPP.

Among cereals rice was dominant. About 84 per cent of all cereals were rice in SPP. As with the national intake cereals also constituted the principal source of various nutrients in SPP diet as can be seen from table-3. This implies the very dependence of SPP inmates on cereals for most of the nutrients. Unlike national intakes the contribution of pulse and oils to different nutrients (especially to protein and energy) accordingly was calculated to be higher with SPP than with the typical Bangladeshi diet. Pulse contributed 
$11 \%$ to energy and $33 \%$ to protein Intake of the SPP beneficiaries. Oil intake contributed $12 \%$ to energy something very unusual in normal Bangladeshi diet. This is very good as all the fat-soluble vitamins turns bio-available with its strong presence in the diet.

Table- 2: Daily per capita food intake by food groups at SPP and in 95-96 National Survey

\begin{tabular}{|c|c|c|c|c|}
\hline \multirow[t]{2}{*}{ Food groups } & \multicolumn{2}{|c|}{ SPP Intake } & \multicolumn{2}{|c|}{ National Intake } \\
\hline & g/person/day & $\%$ Of intake & g/person/day & \% Of intake \\
\hline Cereals & 273 & 34 & 436 & 60 \\
\hline Rice & 230 & 29 & 408 & 56 \\
\hline Wheat & 23 & 3 & 18 & 3 \\
\hline Others & 20 & 2 & 10 & 1. \\
\hline Roots and tubers & 146 & 19 & 72 & 10 \\
\hline Pulses & 58 & 7 & 11 & 2 \\
\hline Leafy vegetable & 22 & 3 & 23 & 3 \\
\hline $\begin{array}{l}\text { Non-leafy } \\
\text { vegetable }\end{array}$ & 192 & 24 & 89 & 12 \\
\hline Fruits & 33 & 4 & 14 & 2 \\
\hline Animal food & 29 & 4 & 61 & 8 \\
\hline Meat & 0 & 0 & 9 & 1 \\
\hline Fish & 4 & * & 33 & 4 \\
\hline Egg & 8 & 1 & 4 & * \\
\hline $\begin{array}{l}\text { Milk and milk } \\
\text { products }\end{array}$ & 17 & 2 & 15 & 2 \\
\hline Edible oil & 24 & 3 & 8 & 1 \\
\hline Miscellaneous & 22 & 2 & 14 & 2 \\
\hline Total & 800 & 100 & 728 & 100 \\
\hline
\end{tabular}

* = Contribution less than 1 percent

Table-3: Contribution of major food groups to different nutrients at SPP as compared to 95-96 National Survey

\begin{tabular}{|c|c|c|c|c|c|c|c|c|}
\hline \multirow[t]{2}{*}{ Nutrients } & \multicolumn{2}{|l|}{ Cereal } & \multicolumn{2}{|l|}{ Pulses } & \multicolumn{2}{|c|}{ Animal Foods } & \multicolumn{2}{|c|}{ Edible oil } \\
\hline & SPP & National & SPP & National & SPP & National & SPP & National \\
\hline Calorie (kcal) & 946 & 1504 & 200 & 48.4 & 45 & 77.7 & 216 & 71.4 \\
\hline$\%$ & 54 & 80.5 & 11 & 2.6 & 3 & 4.1 & 12 & 3.8 \\
\hline Protein $(\mathrm{G})$ & 19 & 29.5 & 14 & 3.0 & 4 & 10.0 & 0 & 0.0 \\
\hline$\%$ & 45 & 62.8 & 33 & 6.5 & 7 & 21.5 & 0 & 0.0 \\
\hline Calcium (mg) & 36 & 47.4 & 48 & 10.3 & 63 & 174.6 & 0 & 0.0 \\
\hline$\%$ & 12 & 14.1 & 16 & 3.0 & 20 & 52.0 & 0 & 0.0 \\
\hline Iron $(\mathrm{mg})$ & 7 & 5.7 & 3 & 0.7 & 0.34 & 0.8 & 0 & 0.0 \\
\hline$\%$ & 39 & 50.0 & 19 & 6.7 & 2 & 7.0 & 0 & 0.0 \\
\hline Vitamin A (IU) & 4 & 3.8 & 84 & 10.6 & 200 & 170.5 & 0 & 0.0 \\
\hline$\%$ & 0.1 & 0.2 & 2 & 0.6 & 4 & 10.2 & 0 & 0.0 \\
\hline Thiamine (mg) & 0.6 & 0.9 & 0.25 & 0.06 & 0.03 & 0.02 & 0 & 0.0 \\
\hline$\%$ & 53 & 84.6 & 21 & 5.1 & 2 & 1.7 & 0 & 0.0 \\
\hline Riboflavin(mg) & 0.2 & 0.3 & 0.11 & 0.06 & 0.1 & 0.06 & 0 & 0.0 \\
\hline$\%$ & 32 & 68.7 & 19 & 12.5 & 17 & 12.5 & 0 & 0.0 \\
\hline Vitamin C(mg) & 0 & 0.0 & 0.20 & 0.05 & 0.8 & 3.1 & 0 & 0.0 \\
\hline$\%$ & 0.03 & 0.0 & 0.33 & 0.16 & 1 & 9.6 & 0 & 0.0 \\
\hline
\end{tabular}

$\beta$-carotene is included in vitamin A 
Table- 4 presents per capita nutrient intake of the SPP beneficiaries. The average intakes of these nutrients for the national population are also shown for comparison and to observe variations between the intakes. Except for vitamin A, the average intake of different nutrients at SPP fell far below the set requirement. The per capita energy intake was found to be $1759 \mathrm{Kcal}$ as against the set requirement of $2039 \mathrm{Kcal}^{5}$. This intake met 86 per cent of daily calorie requirement. Per capita protein intake amounted to be $43 \mathrm{~g}$ and this met 96 per cent of their daily requirement. Table- 3 shows that 46 per cent of total protein came from cereal and 33 per cent from pulses, and virtually almost no intakes from animal food. This implies that SPP population mainly depends on plant sources to meet their daily protein requirement. Of the micronutrients the severest deficiencies were recorded in case of calcium, iron, riboflavin and vitamin C. Average intake of iron was found to be $17 \mathrm{mg} /$ person/day and this met their 77 per cent of total requirement. Among sources of iron cereal contributed about 39 per cent, pulses about 19 per cent, vegetables and fruits about 30 percent and animal food contributed only 2 per cent of total iron intake (table-3). Most of the iron in SPP diet is of plant origin and as stated absorption of iron from plant sources is inhibited due to some interfering compounds. Iron of plant origin is also not fully utilized in the absence of adequate amount of vitamin $\mathrm{C}$ in the diet. Table-4 further reveals that SPP diet lacks adequate amount of vitamin C. The actual intake of iron thus was far short of the set requirements. Table-4 also shows the severe deficiency of riboflavin. They met only 48 per cent of total requirement. The cooking loss has not been taken into account in case of vitamins $\mathrm{A}$ and $\mathrm{C}$ and riboflavin. But loss on this account is as high as 70 per cent in case of vitamin C, 50 per cent for riboflavin and about 20 per cent for vitamin $\mathrm{A}^{6,7}$. If we make allowances for cooking loss, the actual intakes of these limiting vitamins would be much lower than the quoted figures in the table (Table-3). This means SPP will have to be careful in ensuring adequate micronutrient in the diet of the inmates possibly by means of substitution and alteration of the existing weekly menu.

Table- 4: Per capita nutrient intake at SPP and in 95-96 national survey

\begin{tabular}{|l|c|cc|cc|}
\hline Nutrient & Requirement & \multicolumn{2}{|c|}{$\begin{array}{c}\text { SPP Intake } \\
\text { \% of } \\
\text { Requirement }\end{array}$} & \multicolumn{2}{c|}{$\begin{array}{c}\text { National Intake } \\
\% \text { of } \\
\text { Requirement }\end{array}$} \\
\hline Energy (Kcal) & 2039 & 1759 & 86 & 1868 & 92 \\
\hline Protein (g) & 44.6 & 43 & 96 & 47 & 105 \\
\hline Fat (g) & - & 33 & - & 16 & - \\
\hline Carbohydrate (g) & - & 325 & - & 384 & 66 \\
\hline Calcium (mg) & 505 & 307 & 61 & 335 & 11 \\
\hline Iron (m) & 22 & 17 & 77 & 1668 & 97 \\
\hline Vitamin A (IU) & 1712 & 4120 & 240 & 115 \\
\hline Thiamine (mg) & 1.02 & 1.21 & 118 & 1.17 & 39 \\
\hline Riboflavin (mg) & 1.24 & 0.59 & 48 & 0.48 & 70 \\
\hline Vitamin C (mg) & 47 & 61 & 130 & 33 & 15 \\
\hline
\end{tabular}

$\beta$-carotene is included in vitamin $\mathrm{A}$ 
Information on food received by the SPP inmates were collected at two levels and in two ways: at the kitchen levels as reported by the service providers upon supply of the food from storage and at the individual levels actual intakes were recorded using 24-hour food weighing method. A careful examination reveals a gap between the two modes food supply. There is a short fall of about $100 \mathrm{~g}$ of food between the reported and actual intakes. This means that about $12 \%$ of the food supplied from SPP storage did not reach the beneficiaries. This short fall was recorded in case of cereals (wheat flour, pressed and puffed rice) pulses, Powder milk, fish and sweet potatoes (Table-5). Except for sweet potatoes and fish, the spoilage in processing-cooking of these foods is almost nil and the spoilage in sweet potatoes and fish is not much. In case of pulses the shortfall between reported and the actual intake was about $27 \%$, in case of cereals it was $10 \%$, in case of powder milk it was $20 \%$, and in case of fish it was about $75 \%$. SPP should find ways to minimize these leakages. It is to be noted that SPP supplies food to its kitchens on daily basis and no leftover foods was ever noticed within the weekly data collection periods by the Investigators. Table- 6 shows the corresponding shortfall in the intakes of different nutrients between the reported and actual intakes as was noted in the diet. Except for fat, the actual intakes of different nutrients were lower than the reported intake, and the actual intakes fell far short of the requirements.

Table- 5: Per capita food intake difference between kitchen and individual level at SPP

\begin{tabular}{|l|r|r|}
\hline \multicolumn{1}{|c|}{ Food group } & $\begin{array}{c}\text { Intake at kitchen level } \\
\text { (g/person/day) }\end{array}$ & $\begin{array}{c}\text { Intake at individual level } \\
\text { (g/person/day) }\end{array}$ \\
\hline Cereals & 302 & 273 \\
Rice & 231 & 230 \\
Wheat & 34 & 23 \\
Others & 37 & 20 \\
\hline Potatoes & 100 & 100 \\
\hline Sweet potatoes & 64 & 46 \\
\hline Pulses & 80 & 58 \\
\hline Leafy vegetable & 22 & 22 \\
\hline Non-leafy vegetable & 192 & 192 \\
\hline Fruits (Banana) & 39 & 33 \\
\hline Animal food & 46 & 29 \\
Meat & 0 & 0 \\
Fish & 17 & 4 \\
Egg & 8 & 8 \\
Milk & 21 & 17 \\
\hline Edible oil & 24 & 24 \\
\hline Miscellaneous & 26 & 22 \\
\hline Total & 895 & 800 \\
\hline
\end{tabular}


Table- 6: Per capita nutrient intake difference between kitchen and individual level at SPP

\begin{tabular}{|c|c|c|}
\hline Nutrient & Intake at kitchen level & Intake at individual level \\
\hline Energy (kcal) & 1981 & 1759 \\
\hline Protein $(\mathrm{g})$ & 51 & 43 \\
\hline Fat $(\mathrm{g})$ & 35 & 33 \\
\hline Carbohydrate (g) & 367 & 325 \\
\hline Calcium (mg) & 457 & 307 \\
\hline Iron (mg) & 24 & 17 \\
\hline Vitamin A (IU) & 4186 & 4120 \\
\hline Thiamin (mg) & 1.38 & 1.21 \\
\hline Riboflavin (mg) & 0.74 & 0.59 \\
\hline Vitamin C (mg) & 68 & 61 \\
\hline
\end{tabular}

$\beta$-carotene is included in vitamin A

B. Nutritional status of the SPP Beneficiaries: In this section we present findings on the nutritional status of children (up to 9 years), adolescents (10 to 17 years) and adult women ( 18 years and above) as determined by anthropometry. In general we have made use of height and weight to determine the nutritional status. We have used the NCHS standard to classify the nutritional status of the children ${ }^{8}$, and for adults BMI was used to classify them as malnourished or well nourished ?

Table-7 presents the information about the average height, and weight of children of different age groups in the study area. The average height and weight of under- 5 children were recorded to be $87.7 \mathrm{~cm}$ and $11.2 \mathrm{~kg}$ respectively. These figures are quite similar to those of the national figures ${ }^{10}$. It appears from Table- 8 that the average height and weight of children aged 5-9 years were found to be $121.5 \mathrm{~cm}$ and $20.4 \mathrm{~kg}$ respectively. These figures are however higher than the national figures ${ }^{5}$, indicating better nutritional status of children in SPP.

Table-7: A verage height and weight of children of different age groups

\begin{tabular}{|l|l|l|l|}
\hline $\begin{array}{l}\text { Age Group } \\
\text { (years) }\end{array}$ & No. of children & $\begin{array}{l}\text { Height } \\
(\mathrm{cm})\end{array}$ & $\begin{array}{l}\text { Weight } \\
(\mathrm{kg})\end{array}$ \\
\hline$<1$ & 5 & 61.6 & 6.6 \\
\hline 1 & 10 & 72.8 & 8.3 \\
\hline 2 & 10 & 83.2 & 10.6 \\
\hline 3 & 25 & 90.3 & 11.7 \\
\hline 4 & 19 & 101.2 & 13.5 \\
\hline 5 & 36 & 109.5 & 14.9 \\
\hline 6 & 34 & 114.8 & 16.9 \\
\hline 7 & 40 & 121.5 & 20.5 \\
\hline 8 & 43 & 126.1 & 22.5 \\
\hline 9 & 35 & 132.6 & 26.8 \\
\hline $0-5$ & 69 & 87.7 & 11.2 \\
\hline $5-9$ & 188 & 121.5 & 20.4 \\
\hline $0-9$ & 257 & 112.1 & 17.9 \\
\hline
\end{tabular}


In this study child nutritional status was determined by using (a) height for age, (b) weight for age and (c) weight for height and the results are presented in tables according to the age groups.

\section{Height for age}

Deficit in height is an indicator of past chronic under nutrition and provides insights from its long-term perspective. Table- 8 presents the nutritional status of under- 10 children in SPP as per height for age, weight for age, and weight for height classification. Overall one in five children in SPP was found to be stunted. A higher prevalence of stunting was reported with the lower age group of children. It can be seen from Table- 8 that about 46 percent of all under- 5 children were stunted. This was only 9 per cent with children of 5-9 years of age. This is quite alarming and needs more SPP attention. The under-5 stunting prevalence however was comparable with those of the national prevalence ${ }^{10}$. But the situation is somewhat worse when compared with those of the nutritional status of children under HKI surveillance ".

\section{Weight for age}

Low weight for age is defined as "underweight", which is often used to describe the nutritional status of children. According to the weight for age classification of nutritional status, about 30 per cent of all children residing at SPP were underweight. About one in two under-5 children at SPP was under weight. By contrast one in four children in the 5-9 age group was found to be underweight (Table-8). The under-5 prevalence of underweight was comparable with those of similar studies done by both BBS and HKI ${ }^{10}$, 11.

\section{Weight for height}

Deficit in tissue and fat mass compared with the amount expected in a child of same height or length is represented by this nutritional status classification. The term "wasting" is used to describe this type of deficit, and this is an age independent measure of the nutritional status. It appears from Table- 8 that one quarter of all SPP children were wasted. Its prevalence was 22 percent amongst under- 5 and 24 percent with the 5-9 years old children residing at SPP. As with stunting and underweight, the wasting rates of under-5 children at SPP also closely approximate the national prevalence ${ }^{10}$. The rate $(12 \%)$ however was lower with children under HKI surveillance ${ }^{1 !}$. 
Table-8: Prevalence of malnutrition among children of different age groups according to height for age, weight for age and weight for height classification of nutritional status

\begin{tabular}{|c|c|c|c|c|c|c|c|c|c|}
\hline \multirow[t]{2}{*}{ Indicators } & \multirow{2}{*}{$\begin{array}{l}\text { Age (Yrs), } \\
\text { Sample size, } \\
0-5=69,5-9= \\
188,0-9=257\end{array}$} & \multicolumn{8}{|c|}{ Nutritional Status } \\
\hline & & $\begin{array}{l}\text { Nor } \\
\text { No. }\end{array}$ & & $\begin{array}{l}\text { Mil } \\
\text { No. }\end{array}$ & & $\begin{array}{l}\text { Mo } \\
\text { No. }\end{array}$ & $\%$ & $\begin{array}{l}\text { Sev } \\
\text { No. }\end{array}$ & $\%$ \\
\hline \multirow{3}{*}{$\begin{array}{l}\text { Height for } \\
\text { age }\end{array}$} & $0-5$ & 20 & 29.0 & 17 & 24.6 & & 31.9 & 10 & 14.5 \\
\hline & $5-9$ & 145 & 77.1 & 27 & 14.4 & 12 & 6.4 & 4 & 2.1 \\
\hline & $0-9$ & 165 & 64.2 & 44 & 17.1 & 34 & 13.2 & 14 & 5.4 \\
\hline \multirow{3}{*}{$\begin{array}{l}\text { Weight for } \\
\text { age }\end{array}$} & $0-5$ & 11 & 15.9 & 25 & 36.2 & 20 & 29.0 & 13 & 18.8 \\
\hline & $5-9$ & 88 & 46.8 & 56 & 29.8 & 21 & 11.2 & 23 & 12.2 \\
\hline & $0-9$ & 99 & 38.5 & 81 & 31.5 & 41 & 16.0 & 36 & 14.0 \\
\hline \multirow{3}{*}{$\begin{array}{l}\text { Weight for } \\
\text { height }\end{array}$} & $0-5$ & 31 & 44.9 & 23 & 33.3 & 10 & 14.5 & 5 & 7.2 \\
\hline & $5-9$ & 63 & 34.1 & 5 & 40.5 & 23 & 12.4 & 24 & 13.0 \\
\hline & $0-9$ & 94 & 37.0 & 98 & 38.6 & 33 & 13.0 & 29 & 11.4 \\
\hline
\end{tabular}

Body Mass Index popularly known as BMI [weight (in kg)/height (in meter) ${ }^{2}$ ] represents short-term malnutrition among adults. Reference data for BMI are based on the first National Health and Nutrition Examination Survey (NHAESI), United State of America. According to this reference $5^{\text {th }}$ percentiles represents the lowest and $85^{\text {th }}$ percentiles indicates the highest cut-off values for normal range of BMI for age. Table-9 shows the BMI of the SPP adolescents using this cut off points. It appears from the table that about 14 percent of the all adolescents at SPP had low BMI. It was however higher with the boys than with the girls. The good news is that the vast majority of them were found to be normal.

Table-9: Nutritional status of adolescents by considering the cut-off points of age groups 1017 years according to Body Mass Index (BMI)

\begin{tabular}{|c|c|c|c|c|c|c|}
\hline \multirow[t]{2}{*}{ Indicator } & \multicolumn{2}{|c|}{ Male } & \multicolumn{2}{|c|}{ Female } & \multicolumn{2}{|c|}{ Both } \\
\hline & No. & $\%$ & No. & $\%$ & No. & $\%$ \\
\hline Normal & 34 & 79.1 & 33 & 86.8 & 67 & 82.7 \\
\hline Thinness & 8 & 18.6 & 3 & 7.9 & 11 & 13.6 \\
\hline Overweight & 1 & 2.3 & 2 & 5.3 & 3 & 3.7 \\
\hline Total & 43 & 100 & 38 & 100 & 81 & 100 \\
\hline
\end{tabular}

Table- 10 presents the prevalence of malnutrition among SPP adult women according to BMI. FAO/WHO/UNU used 18.5 as the cutoff point to identify chronic energy deficiency in adults. According to this criteria an adult female with BMI [weight (in $\mathrm{kg}$ )/height (in meter) $)^{2}$ less than 18.5 is termed as undernourished, and an adult women with BMI above or equal to 18.5 is treated as normal. Then a BMI greater than or equal to 25.0 is considered as obese.

It appears from the table-10 that about two thirds of all women residing at SPP are normal leaving the other quarter as malnourished. Among the malnourished 25 percent were very young between the age group of 18 and 19. It is interesting to note that about 9 
per cent of the middle-aged women at SPP were also found to be obese. SPP will have to be careful in dealing with these women, especially in respect of their diet and life style patterns.

Table- 10: Prevalence of malnutrition among women (18-44 years) according to BMI

\begin{tabular}{|l|rc|cc|cc|}
\hline Age group (years) & \multicolumn{2}{|c|}{ Normal } & \multicolumn{2}{c|}{ Malnourished } & \multicolumn{2}{c|}{ Obese } \\
& No. & $\%$ & No. & $\%$ & No. & $\%$ \\
\hline $18-19(n=4)$ & 3 & 75.0 & 1 & 25.0 & 0 & 0.0 \\
\hline $20-24(n=23)$ & 19 & 82.6 & 3 & 13.0 & 1 & 4.3 \\
\hline $25-29(n=34)$ & 27 & 79.4 & 6 & 17.6 & 1 & 2.9 \\
\hline $30-34(n=34)$ & 25 & 73.5 & 6 & 17.6 & 3 & 8.8 \\
\hline $35-39(n=14)$ & 9 & 64.3 & 1 & 7.1 & 4 & 28.6 \\
\hline $40-44(n=4)$ & 3 & 75.0 & 0 & 0.0 & 1 & 25.0 \\
\hline Total $(n=113)$ & 86 & 76.1 & 17 & 15.0 & 10 & 8.8 \\
\hline
\end{tabular}

\section{Reported Morbidity at SPP}

Table-11 provides information on the prevalence of short-term morbidity in last two weeks prior to survey team's visit at SPP. It is to be noted that out of those who reported morbidity ( 158 individuals), 39\% (61 children) was under-5. Out of this children over $80 \%$ (50 out of 61 children) reported skin disease implying that skin disease is wide spread among children. About $75 \%$ (31 out of 41 ) of above-5 children (5-9 years of age) reporting morbidity also suffered from skin disease. This is really very alarming. This might be something very seasonal emerged with the advent of summer and has linked with the crowded living conditions of the inmates. In Bangladesh $35 \%$ of all child death is all because of diarrhea ${ }^{12}$, but this was virtually absent in SPP. This must be attributed to safe water use, sanitation and better personal and environmental hygienic at SPP, and the strong supervision from SPP authorities on them. SPP campus was quite neat and clean and the sanitation facilities were unlike other typical rural areas of Bangladesh. SPP deserve deep appreciation for this. As can be seen from Table- 12 the other short-term diseases (such as URI, angular stomatitis, gastric etc.) were not very pronounced at SPP.

Table-11: Reported short-term morbidity among SPP inmates

\begin{tabular}{|l|c|c|l|l|c|}
\hline \multirow{2}{*}{ Disease } & \multicolumn{5}{|c|}{ Age group (years) } \\
\cline { 2 - 6 } & $\begin{array}{l}\text { Children } \\
\text { Under-5 }\end{array}$ & $\begin{array}{l}\text { Children } \\
5-9\end{array}$ & $\begin{array}{l}\text { Adolescents } \\
10-17\end{array}$ & $\begin{array}{l}\text { Adult } \\
18 \text { and above }\end{array}$ & All ages \\
\hline Diarrhea & $0.6(1)$ & 0 & 0 & $0.6(1)$ & $1.2(2)$ \\
\hline Skin disease & $32.0(50)$ & $20.0(31)$ & $6.0(10)$ & $0.6(1)$ & $58.6(92)$ \\
\hline Viral fever & $3.0(5)$ & $2.0(4)$ & $4.0(6)$ & $2.0(4)$ & $11.0(19)$ \\
\hline Others & $3.0(5)$ & $4.0(6)$ & $3.0(5)$ & $18.0(29)$ & $28.0(45)$ \\
\hline Total & $39.0(61)$ & $26.0(41)$ & $13.0(21)$ & $22.0(35)$ & $100.0(158)$ \\
\hline
\end{tabular}

Figure in parenthesis indicates number 


\section{Discussion}

The study findings are encouraging in that the dietary intakes and anthropometry of the SPP beneficiaries are comparable to those of their counterparts in the rural Bangladesh. This implies that without SPP interventions and attention the real life situation for these inmates would have been different, and only the fate would rule and decide their destiny. SPP has been trying very hard to bring meaningful changes in the life and living of these destitute. SPP has been pursuing a holistic approach and wants to address all its inmates' problems from both qualitative and quantitative perspectives. But there are inherent lapses needing critical review. Though the dietary intakes of the SPP inmates were more varied than those of the rural poor, the diversity in its present form is not nutritionally desirable. This makes them vulnerable to hidden hunger. Nutritionally lower quality vegetables and roots dominated the SPP diet and the virtual absence of animal food compromised the diet quality. Leafy vegetables and fruits intakes were very low and lagged far behind their set requirements. Inclusion of animal food and fresh fruits has the potential to improve diet diversity by improving the iron, vitamin and mineral deficiencies among SPP inmates. The finding thus suggests that the management of SPP and the care givers (adult women residing at SPP) be exposed to nutrition education. This might help them to incorporate right kind of food items to the diets for nutritional betterment of the destitute child and women. Then the study recorded some irregularities between the reported and the actual intakes of pulse, fish, cereals (wheat flour, pressed and puffed rice), powder milk, and sweet potatoes. This needs a careful investigation. Anthropometric assessments of the inmates indicated the presence of double burden of malnutrition at SPP. The great majority of the children (specially under5) were undernourished; while at the same time about $9 \%$ of all adult women were found obese (BMI $>25$ ). SPP added attention is needed to address these issues. The total intakes of these children need to be increased with added animal food and palatable diets. The obese women should be exposed to physical exercise and to non-formal awareness education.

Finally the study findings suggest that this kind of social endeavor should thus recommend to be replicated by the government at least at the divisional level. If adequate resources are being found, establishment of such rehabilitation centre at the district level will definitely contribute in identifying destitute women and children and undertake appropriate welfare measures for them.

\section{Acknowledgement}

I would like to offer my gratitude and sincere thanks to Md. Nazrul Islam, Computer Programmer - cum - System Analyst, INFS, Dhaka University for all his assistance in data management and analysis. I am especially grateful to Rukhsana Kana and Taslima Sultana, former students of INFS and Home Economics College for their constant cooperation and support throughout the whole period of my study. 


\section{References}

1. Hossain M. The assault that failed, a profile of absolute poverty in six villages of Bangladesh. Geneva, UNRISD, 1987.

2. Chen MA. A quiet revolution woman in transition in rural Bangladesh, Dhaka. BRAC, Prokashana, 1986.

3. Yunus M. Jorimon of Beltoil village and others, in search of a future. Dhaka, Grameen Bank, 1984.

4. Darnton-Hill 1, Hassan N, Karim R, Duthie MR. Tables of nutrient composition of Bangladesh foods: English version with particular emphasis on vitamin A content. Helen Keller International, Dhaka, Bangladesh, 1988.

5. Jahan K, Hossain M. Nature and Extent of malnutrition in Bangladesh. Bangladesh National nutrition Survey, 1995-96. Institute of Nutrition and Food Science, University of Dhaka, 1998.

6. Nahar B, Banu C.P, Ahmed K. Loss of Nutrients of Food stuffs on cooking: Bangladesh Journal of Agriculture Vol. 7 no. 2. Bangladesh Agricultural Research Council, Dhaka, 1982.

7. Nahar B, Banu C.P, Malek A, Salamatullah Q. Institute of Nutrition and Food Science, University of Dhaka, Bangladesh, 1988.

8. Hamil et al. Physical growth; National Center for Health Statistics Percentiles. American Journal of Clinical Nutrition, Vol 32, 607-629, 1979.

9. James W.P.T and Schofield E.C. Human energy Requirements: A Manual for Planners and Nutritionist. FAO, Oxford Medical Publications, 1990.

10. BBS (Bangladesh Bureau of Statistics), GOB (Government of the People's Republic of Bangladesh). Child Nutrition Survey of Bangladesh 2000, Statistics 2000. Bangladesh Bureau of Statistics, Statistics Division, Ministry of Planning, Government of the People's Republic of Bangladesh, Dhaka, and UNICEF. January, 2002.

11. Bangladesh in Facts and Figures: 2004 Annual Report of the Nutritional Surveillance Project. Helen Keller International, Institute of Public health Nutrition, Dhaka, Bangladesh, 2005.

12. Kana R. Micro credit, Nutrition and Health: A Study in Selected Rural locations of Bangladesh. M.S. Thesis. Institute of Nutrition and Food Science, University of Dhaka, pp 33 , October, 2005. 